\title{
English for Agriculture Vocational School Students: A Need Analysis Study at SMK Negeri 2 South Bengkulu
}

\author{
Desi Veranita \\ Syahrial \\ Irwan Koto \\ University of Bengkulu \\ Bengkulu, Indonesia 38371 \\ desiveranita@gmail.com \\ eric.syahrial@gmail.com
}

\begin{abstract}
This research was aimed to identify the need of the students of agriculture study program on English materials. This research focused in find out the most important English skills and SubSkills for the students of agriculture study program and find out the English topics are needed for the students of agriculture study program at SMK Negeri 2 South Bengkulu. The research used mix method (combine both qualitative and quantitative method). This research was conducted in Agriculture Vocational School 2 South Bengkulu (SMK Negeri 2 South Bengkulu). The data was taken from the assistance of curriculum, the English teachers, productive teachers and the alumni of SMK Negeri 2 South Bengkulu. The data was collected by using questionnaire and interview. The result of the research shows that: first, the most important English skills for the students of agriculture study program at SMK Negeri 2 South Bengkulu are Speaking and Reading Skills. Reading sub-skills classified as; reading in general comprehension, understanding the plan of the text, guessing the meaning of unfamiliar words, do skimming and scanning activities and understanding the organization of the text. Speaking sub-skills classified as; speaking with fluency, attention of choice and pronunciation and using the correct ways/ manners of speaking. Second, English topics for the students of agriculture were the English topics related to the agriculture term. The topics of reading were; reading the text of part of plants, reading the text of the technique of maintenance of plants and operating hart equipment farming. The topics of speaking were; do direct conversations related to agriculture terms, presenting the report of filed productive practice, describing of how to operate hard equipment farming and maintenance of the plants.
\end{abstract}

Key words: Need Analysis, English for Agriculture Students. 


\section{INTRODUCTION}

English learning materials are kind of subject which learned for the students to support the students in mastering English either English for general language or English for specific purposes. According to Tomlinson (2001) the materials can be anything that is useful for studying. Materials are anything used to assist students in language learning. They can be in the form of textbook, workbook, cassette, CD-Rom, video, photocopied handout, newspaper, paragraph written on the whiteboard or anything which presents or informs about the language being learned.

The materials that will be taught to the students should match with the students need. Additionally, both English for Academic Purposes (EAP) and English for Specific Purposes (ESP) must be practiced among the students, particularly for the students on vocational schools as SMK Negeri 2 South Bengkulu of Agriculture: Agribusiness and Agro Technology Study Program. The agriculture vocational school is a school which is prepared the students for organized in workplace, academic, and professional. Therefore, ESP textbook must fulfill some of the students need (Karimi and Sadeghi, 2013).

Need analysis is the most important stage in English for Specific Purposes (ESP). Needs analysis has a vital role in the process of designing and carrying out any language course, whether it is English for Specific Purposes (ESP) or general English course (Songhori, 2008). Needs analysis is defined as a process of determining the needs of a group of learners that requires a language and arranging the needs according to priorities where it uses both subjective and objective information (Richards, 1992).

SMK Negeri 2 South Bengkulu is one of high vocational school in Spouth Bengkulu. The school focuses on agriculture department, and it is divided into four study program; Plantation Corps (ATP), Seeding Plant Tissue Culture (APKJT), Horticultural (ATPH), and Animal Husbanding (ATU). According to the researcher knowledge, implementing the materials based on the students need is very important in SMK Negeri 2 South Bengkulu because some of the reasons, there are:

The first are English for agriculture is type of English for specific purposes. The English materials should suitable with the need of the students, whether used for reading the agriculture theories or practicing the theories on the field or for preparing the students for facing the world of work. Rata, et al (2012) state that English for agriculture is a type of English for specific purposes.

The second are SMK Negeri 2 South Bengkulu is implementing the curriculum 13 (Kurikulum K13) as a basis of teaching learning activities. The 13 curriculum (K 13) was developed based on current globalization and various issues related to environmental issues, technological advances and information, the rise of the creative and cultural industries, and the development of education at the international level. Globalization will shift the lifestyle of the people of agrarian and trade traditionally been industrial society and modern trade as can be seen in the World Trade Organization (WTO), the Association of Southeast Asian Nations (ASEAN) Community, the Asia-Pacific Economic Cooperation (APEC) and ASEAN free Trade Area (AFTA) (Kemendikbud, 2012).

The curriculum 2013 (K 13) aims to prepare the Indonesian man to have the ability for live as individuals and citizens who believe, productive, creative, innovative, and affective and able to contribute to the society, nation, state, and world civilization (Permendikbud no 70, 2013). 
The principles in preparing the curriculum have been referring to the principle of development (Permendiknas $22,2006)$. The principles are centered on the potential of the development, the needs and the interests of the learners and the environment. The position of the learners are as central of education, learners are the subject of education that should develop their competence and relevant to the needs of life; community, the business world and the world of work. Thus, the teaching materials should provide to the students to support the students' needs (Depdiknas, 2006).

The third are the primary goals of SMK Negeri 2 South Bengkulu are to equip the students with the education and to train through actual competencies which are needed in business or industry world (Internal Document of SMK Negeri 2 South Bengkulu: 2011). Javid (2013) define that ESP was teaching of English for any purposes that could be specified and teaching of English used in academic studied or teaching of English for vocational and professional purposes.

Practicing English learning materials based on the students need are giving many advantages because the students are expected to achieve various abilities that has something to do with career, competency, flexibility, encouragement to build up a professional attitude in their field, create the students who capable to enlarge themselves in the future independently through on higher education.

Therefore, the materials presented to the students in SMK Negeri 2 South Bengkulu have to comply with the students need based on the background of their school. Harding (2007) suggested three recommendations to consider while coming up with a set of materials; Use context, texts, and situations from the students' subject area. Whether they are real or stimulated they will naturally involve the language the students' need, Exploit authentic materials that students use in their specialism or vocation. Do not be put off by the fact that it may not look like 'normal English', Make the tasks authentic as well as the tasks. Get the students doing things with the materials that they actually need to do their work.

Based on the background above can be inferred that implementing English learning materials based on the students need is very important for maximizing the benefits and the goals of learning English for the students.

\section{METHOD}

This research used mixed method (collection of qualitative and quantitative data). Mixed methods involve the collection and "mixing" or integration of both quantitative and qualitative data in a study. In this approach, a researcher collects both quantitative and qualitative data, analyzes them separately, and then compares the results to see if the findings confirm or disconfirm each other (Convergent Parallel Mixed Methods Design).

According to Creswell (2014)
mixed method is used Both predetermined and emerging methods, both open and closed-ended Questions, several forms of data drawing on all possibilities, Statistical and text analysis, Across databases interpretation. The purposes of mixed methods are containing the overall intent of the study and the information about both the quantitative and qualitative technique of the study, and a rationale of incorporating both techniques to study the research problem (Creswell, 2014).

\section{The Respondent of the Research}

The respondent in this research was the English teachers at SMK Negeri 2 South Bengkulu, productive teachers, the assistant of curriculum and the alumni of SMK Negeri 2 South Bengkulu. According to Sugiyono (2010) the participants are the generalization region consisting of objects or subjects that have certain qualities and characteristics 
defined by the researchers to be studied and then drawn conclusions.

The total respondent were used in this research divided into 15 respondents, they are; 2 English teachers, 6 teachers of productive program, 1 the assistant of curriculum and 6 the alumni of SMK Negeri 2 South Bengkulu.

The alumni who was interviewed are work in some of place which are fixed in the agriculture divisions. One of the alumni works in the agriculture office of South Bengkulu, in PT. SBS company South Bengkulu as the employee, in CV Sinar Tani Pino Raya as the worker, as the teacher in Vocational School 2 South Bengkulu, and the owner in Tani Mandiri store which provide the agriculture materials such; seed, fertilizers, toxic, and the others.

\section{Research Instrument}

In order to collect the data of the research, the researcher used interview techniques and questionnaire (closeended question).

According to Margono (2014) interview is a technique which are collect the data by filing each number of questions orally to be answered orally. Interview is a process of getting the information of the research that is being done.

According to Sugiyono (2010) questionnaire is the technique of collecting the data by giving some of the questions or statement to the respondent. In close-ended questionnaire, respondent were given 3 options and can only choose one fix answer/statement.

\section{Need Analysis Interview}

The interview was given to the respondents of 1 English teacher, 1 the assistant of curriculum, 1 productive teacher and 1 alumni of agriculture vocational school 2 south Bengkulu (SMK Negeri 2 South Bengkulu). The questions of interview were in Bahasa Indonesia and it is covered of 10 questions.

\section{Need Analysis Questionnaire}

This Questionnaire was given to the respondents of 2 English teachers, 1 the assistant of curriculum and 6 productive teachers and 6 alumni of Agriculture Vocational School 2 South Bengkulu (SMK Negeri 2 South Bengkulu). This question included of English language skills/sub-skills and English topics. It covered four English skills and each skill divided into several topics/ statements.

\section{The Technique of Analysis Data}

The challenge in a convergent mixed methods design is how to actually converge or to merge the data. There are several ways to combine the two databases. The first approach is called a side-by-side comparison. These comparisons can be seen in the discussion sections of mixed methods studies. The researcher will first report the quantitative statistical results and then discuss the qualitative findings that either confirm or disconfirm the statistical results. On the other hand, the researcher might start with the qualitative findings and then compare them to the quantitative results. Mixed methods writers call this a side-by-side approach because the researcher makes the comparison within a discussion, presenting first one set of findings and then the other (Creswell, 2014).

\section{Quantitative statistical result}

The quantitative data was achieved from the questionnaire given to the respondents of the research. Since each question in questionnaire has been answered, the result was based on the percentage of answer. The percentage of the answer was achieved by using the following formula:

$$
p=\frac{f}{\sum f} 100 \%
$$

$\mathrm{f} \quad$ : frequency of respondents of each statement

$\sum \mathrm{f} \quad$ : number of respondents in whole for the alternative Question 


\section{Interval for Mean Interpretation}

Since the questionnaire gave 3 alternatives ( 1 to 3 ) of answers, the interval of each category will be obtained by the formula:

$$
p=\frac{n-1}{n}
$$

$\mathrm{p} \quad$ : length of interval

n : number of alternative

$$
p=\frac{3-1}{3}
$$

In this research, the $p$ was 0,6

\section{Interpretation}

Table 3. Mean Interpretation

\begin{tabular}{|l|l|}
\hline \multicolumn{1}{|c|}{ Score } & \multicolumn{1}{c|}{ Interpretation } \\
\hline $2,4-3$ & $\begin{array}{l}\text { Very important } \\
\text { (strongly important) }\end{array}$ \\
\hline $1,7-2,3$ & Important (positive) \\
\hline $1-1,6$ & Not important (negative \\
\hline
\end{tabular}

\section{Qualitative Result}

After gathering the information of the interview and questionnaire from the respondents, the researcher analyzes the data by:

a. writes the conversation transcript

The Researcher creates or rewrites each interview conversation conducted with the respondents by repeating the record and reading important notes written by researchers during the interview.

b. Classification the data / information

After the researcher rewrites the interview conversation, the researcher categorized the various answers into the categories of information needed by the researcher as an answer to the problem that was asked in this research.

\section{c. Writing the conclusion}

The next steps are the researcher writes the conclusions of all the data gathered from the respondents to each question submitted. d. Describe the result

Based on the objectives of this research, the researcher is classifying the answers obtained from the interview.

\section{Combination of Qualitative and Quantitative Result}

The final steps are the researcher combines both qualitative and quantitative data gathered by using two ways of analysis the data of mixed method based on Creswell theory (2014). The first approach is called a side-by-side comparison. These comparisons can be seen in the discussion sections of mixed methods studies. The researcher will first report the quantitative statistical results and then discuss the qualitative findings that either confirm or disconfirm the statistical results. On the other hand, the researcher starts with the qualitative findings and then compares them to the quantitative results. Mixed methods writers call this a side-by-side approach because the researcher makes the comparison within a discussion, presenting first one set of findings and then the other (Creswell, 2014).

\section{FINDING}

\section{English Skills}

The most important English language skills for students of agriculture study program are speaking skill and reading skill. There was a figure that showing the percentages of the skills are needed for the students of agriculture studyprogram; 
Figure 1

The most needed English skills for the students of agriculture

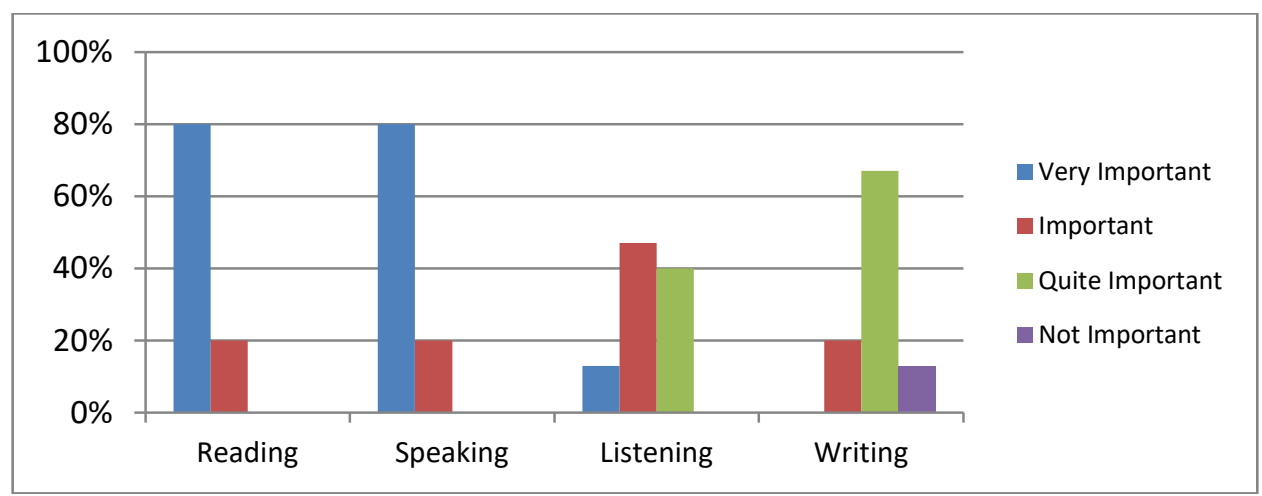

The figure 1 indicated $80 \%$ respondents measured that reading skills is the most useful skills should be mastered for the students of agriculture study program. Then, the similar result in figure 1 showed that $80 \%$ respondents were very agree that speaking skills is the most important skills should be mastered for the students of agriculture study program. Both skills are getting

the highest percentage of English skills to be mastered for the students of agriculture study program.

\section{English Sub- Skills}

There were several ways (subskills) required by the students of agriculture study program for mastering reading and speaking skills. The table below were classified the sub-skills should be applied in activities;

Table 2

Reading sub-skills for the students of agriculture study program

\begin{tabular}{|l|c|c|c|}
\hline \multirow{2}{*}{ Reading Sub-Skills } & \multicolumn{3}{|c|}{ Percentages } \\
\cline { 2 - 4 } & Very Important & Important & Not Important \\
\hline Reading in general comprehension & $100 \%$ & 0 & 0 \\
\hline Understanding the plan of the text & $100 \%$ & 0 & 0 \\
\hline Making prediction of the topics & $20 \%$ & $80 \%$ & 0 \\
\hline Local comprehension & $13 \%$ & $87 \%$ & 0 \\
\hline Guessing the meaning of unfamiliar worlds & $100 \%$ & 0 & 0 \\
\hline Do skimming & $100 \%$ & 0 & 0 \\
\hline Do scanning & $100 \%$ & 0 & 0 \\
\hline Understanding the organization of the text & $100 \%$ & 0 & 0 \\
\hline Making short note & $73 \%$ & $27 \%$ & 0 \\
\hline
\end{tabular}

Table 2 showed the activities should be implemented in reading class for the students of agriculture study program, those were; reading in general comprehension, understanding the plant of the text, guessing the meaning of unfamiliar words, do skimming and scanning activities and the last understanding the organization of the text.

There were some of speaking activities should be implemented in speaking class. It was showed in figure 2 ; 
Figure 2

Speaking sub-skills for the students of agriculture study program



Figure 2 showed the most important speaking sub skills in English class for the students of agriculture, that are; speaking with fluency, taught the accuracy with words and pronunciation, use the true vocabulary, use correct ways/manners of speaking.

\section{English Topics}

Table 3 demonstrated reading topics are needed for the students of agriculture study program at SMK Negeri 2 South Bengkulu;

Table 3

Reading topics for the students of agriculture study program

\begin{tabular}{|l|c|c|c|}
\hline \multirow{2}{*}{ Reading topics } & \multicolumn{2}{|c|}{ Percentages } \\
\cline { 2 - 4 } & $\begin{array}{c}\text { Very } \\
\text { Important }\end{array}$ & Important & $\begin{array}{c}\text { Not } \\
\text { Important }\end{array}$ \\
\hline Reading text related to agriculture terms & $67 \%$ & $33 \%$ & $0 \%$ \\
\hline Reading text of part of plants & $87 \%$ & $13 \%$ & $0 \%$ \\
\hline $\begin{array}{l}\text { Reading the instruction of using tractor/ hard } \\
\text { equipment farming }\end{array}$ & $73 \%$ & $27 \%$ & $0 \%$ \\
\hline $\begin{array}{l}\text { The instruction of using laboratory } \\
\text { instrument }\end{array}$ & $73 \%$ & $27 \%$ & $0 \%$ \\
\hline Reading text of part of farming instruments & $60 \%$ & $40 \%$ & $0 \%$ \\
\hline Reading technique of maintenance of plants & $80 \%$ & $20 \%$ & $0 \%$ \\
\hline Reading technique of irrigation & $80 \%$ & $20 \%$ & $0 \%$ \\
\hline Reading the instruction of using fertilizer & $80 \%$ & $20 \%$ & $0 \%$ \\
\hline Reading text of marketing product & $80 \%$ & $20 \%$ & $0 \%$ \\
\hline Reading report of productive practice & $67 \%$ & $33 \%$ & $0 \%$ \\
\hline Reading scholarship advertisement & $53 \%$ & $40 \%$ & $7 \%$ \\
\hline Reading job advertisements & $73 \%$ & $27 \%$ & $0 \%$ \\
\hline
\end{tabular}


Table 3 showed the most useful reading topics related to agriculture terms were very important for the students of agriculture study program, that are reading part of plants, reading technique of maintenance of plants, reading technique of irrigation, reading the instruction of using fertilizer, reading text of marketing products, reading the instruction of using tractors/ hard equipment farming, reading the instruction of using laboratory instrument, reading job advertisement, reading text related to agriculture terms, reading report of productive practice, reading part of farming instrument, and reading scholarship advertisement.

The most useful speaking topics related to agriculture terms were very important were illustrated in the figure below:

Figure 3

The result of speaking topics are needed for the students of agriculture study program

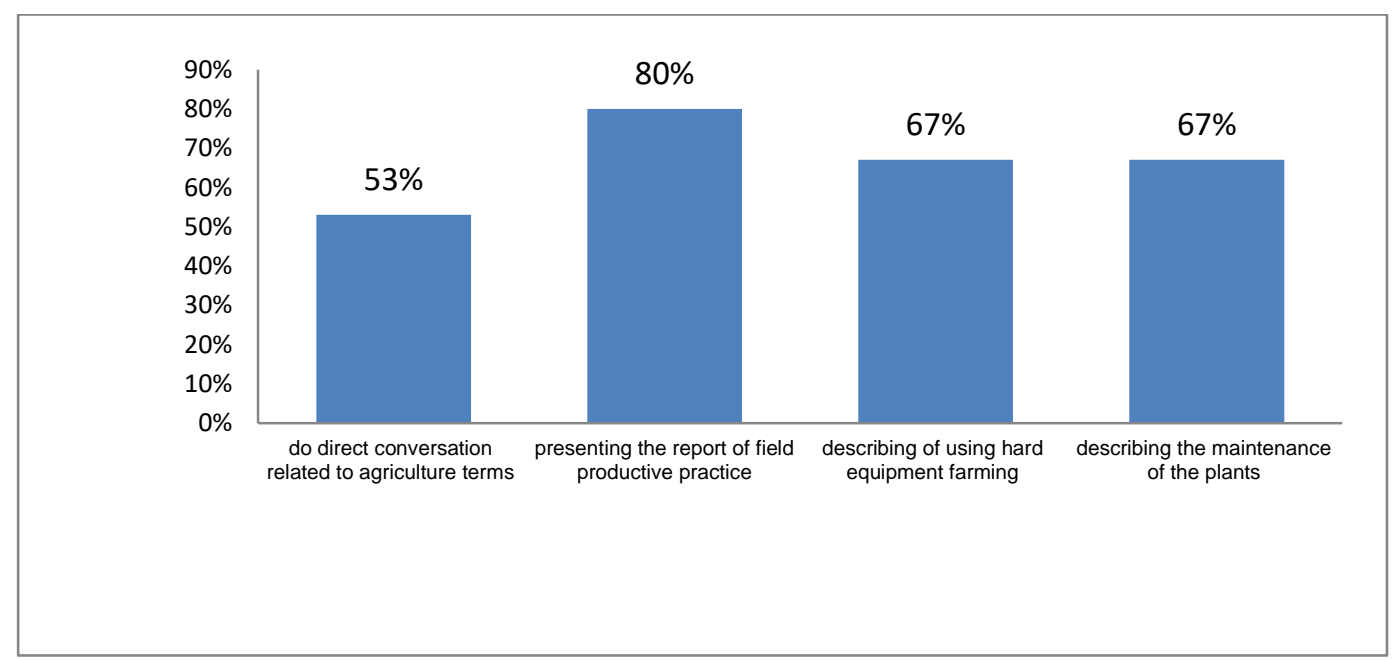

Figure 3 showed the most useful speaking topics and activities should be presented in speaking class, those were: do direct conversation related to agriculture terms, describe of using hard equipment farming orally, describe of maintenance the plants orally and presenting the field practice.

\section{DISCUSSION}

Finding out the needed of the students of agriculture in learning English are very important. As Bastrukmen (2010) stated that Target situation analysis is a process to identification of the learning tasks, activities and skills learners are/ will be using English for. Accordingly, identification the most needed English skill, English sub-skills and English topics for the students of agriculture study program are very important. The data collected explain that implementing the English materials related to agriculture terms will give many highquality effects for the students of agriculture study program at SMK Negeri 2 South Bengkulu.

The information and the data collected previously find that the most important skills for the students of agriculture study program are reading and speaking skills. Reading skills is very useful for the students of agriculture because the language contained in the vocational textbooks used by the students in the classroom or contained in the package of agricultural 
products and in the hard equipment farming used by the students to practice in the field are still using English and do not translate into Indonesia.

Meanwhile, the students of agriculture study program did not mastering English agriculture well because they were not implementing English agriculture in the classroom. It was make them difficult in understanding the information being read. Thus, deliver English language teaching materials related to agriculture terms will greatly help the students of agriculture achieve the learning objectives of vocational materials, such as; reading topics related to agriculture terms are reading part of plants, reading technique of maintenance of plants, reading technique of irrigation, reading the instruction of using fertilizer, reading text of marketing products, reading the instruction of using tractors/ hard equipment farming, reading the instruction of using laboratory instrument, reading job advertisement, reading text related to agriculture terms, reading report of productive practice, reading part of farming instrument, and reading scholarship advertisement.

All the topics above was supporting the students in following the instruction of using hard equipment farming, how to use the fertilizer, planting the seeds based on the instruction and understanding the information contained in the agriculture textbook that are using English. It is claimed that the topics is useful to provide students with general and academic vocabulary which is done through word formation (Karimi, Sadeghi, et al: 2013).

The result finding was similar with the English for Agriculture from Mounfort (2013). He was explained some of English topics for Agriculture in his book, those are; the activities of reading and comprehension which are labeling the diagram and read the text of the definition part of a plant and general statement of the functions of the topics, reading texts related to the process of life cyrce of a plan, reading texts related definition, description and identification of draining and irrigation, reading the text of Manures and fertilizers, reading the text of control of weeds and plant disease and the last are reading the text of market gardening/ marketing products.

Mazdayasna and Tahririan (2008) claimed that presenting reading topics of agriculture terms serves two functions: first, it provides opportunities for practicing linguistic features of the text in different forms and context. Another one is prevention of boredom and the last feature that we deem essential is providing opportunities for practicing extensive reading. Considering these features, it is strongly claimed that the present volume is much superior to any other similar reading topics in helping students of agricultural improve their reading comprehension

Comparing the data above was persuading the researcher that implementing the English topics in reading activities related to agriculture terms are very important and will giving the excellent effect for the agriculture students. Another advantage in implementing English for agriculture for the students of agriculture at SMK Negeri 2 South Bengkulu are make the students know the function of English they are learned and will motivated them in learning English because they were knowing the goals the English to be. It was similar with the statement of the function of analysis the students need in learning English from (Munby,1978 in Tahir, 2011) that learning needs can be viewed from Psychological \& cognitive needs. It means that implementing English materials related with the students need will show up the 
students motivational, recreational and emotional needs.

Speaking skill is very useful for preparing the students of agriculture study program for facing the world of work after finished their study at the vocational high school. Nowadays, finding work is too difficult for everyone, especially for the people which are not have special ability or good communication ability. The international language that be approved in the world are English language, the language could be used in everywhere.

Speaking skills give many impacts is almost all sectors around the human life, such as; in economic, business, social, touris, and eduction. In every country, especially the country that using English as the foreign language, English as one the language should be mastered for the human works.

It can be seen from the fact that the ASEAN countries has entered into a declaration of cooperation called ASEAN Economic Community (AEC), it is mean that every citizen of the State of AEC are free to seek work or create jobs in the countries included in AEC, such INDONESIA. Therefore, mastering English language should be possessed for students of agricultural in SMK Negeri 2 South Bengkulu to enable them in facing work competition in global labor. It also will open the employment opportunities for the students of agriculture in SMK Negeri 2 South Bengkulu.

Zaremba (2006) pointed that speaking skills were usually placed ahead of work experience, motivation, and academic credentials as criteria for new recruitment of employment. For that reason, speaking activities related to agriculture terms are very important to be practiced, Such as; speaking with fluency, taught the accuracy with words and pronunciation, use the true vocabulary, use good grammar and use correct ways/ manners of speaking during do speaking activities in English class.

Other than, from the experience of the learner who following the national competition in recent years, mastering speaking skills related to agriculture terms are very important to be mastered, it is because when they were presenting the report of field activities to the audience they must presenting by using English.

The most useful speaking topics and activities should be presented in speaking class, those were: do direct conversation related to agriculture terms, describe of using hard equipment farming orally, describe of maintenance the plants orally and presenting the field practice. The speaking topics and activities are very useful to train the students mastering speaking English very well, whether used to communicate or used to present the productive report.

The result finding was demonstrated the appropriate English materials for the students of agriculture study program at SMK Negeri 2 South Bengkulu. The students are needed taught the English materials which are suitable with their need. They are not only need learning the general English as usual but also they are needed learning English in specifically which are connected with the background of the students. It is because they will know the function of English they were learned and will be very useful for their life. They just do not learn English because English materials are kinds of the subject of the school but they know for what they are learning English. 


\section{CONCLUSION}

This research produced very useful information related to need analysis, specifically a need analysis of English materials for the students of agriculture study program at SMK Negeri 2 South Bengkulu. The result of this research showed the obvious conclusions based on the finding and the discussion described previously.

First, the findings and the discussions showed that $80 \%$ respondents measure that the most important English skills for the students are speaking and reading skills. Both skills are giving greatly effects for the students of agriculture in learning English. Then, the following conclusion was the most reading and speaking subskills are needed for the students of agriculture study program. Reading sub skills are needed for the students of agriculture were; reading in general comprehension, guessing the meaning in unfamiliar works, doing reading exercises through scanning and skimming and the others. Speaking sub skills are needed for the students of agriculture was investigated in this research were; speaking with fluency, attention of choice and pronunciation, use correct ways/manners of speaking.

The second result in this research was showing the most important English topics for the students of agriculture study program. It was investigated and explained in each English skill (reading and speaking skills). This research found that English topic for reading was preseting the text related to the agriculture terms, that are; reading text related to part of plants, reading text related to technique of maintenance of plants, reading text related to the technique of irrigation, reading the instruction of using tractors/ hard equipments farming, reading text related to the instruction of using laboratory instruments and reading report of productive practice. English topics for speaking should be practiced in English class for the students of agriculture were; presenting the report of field productive practice, describing the instruction of using hard equipment farming, describing the maintenance of plants and do direct conversation related to another agriculture terms.

\section{SUGGESTION}

The researcher suggested this research to:

\section{The Teacher}

For the English teachers who teach at Agriculture Vocational School, they can implementing the English materials based on the agriculture terms or based on the English topics presented in this research.

\section{The Further Researcher}

The result of this research may have some flaws because the researcher did not get the information from the students of agriculture study program at SMK Negeri 2 South Bengkulu. For the other researcher who interest in analysis English for agriculture students, the researcher recommends to analyze the students need based on the students' perspectives itself. The researcher wishes that the next research will find the larger information about the students need, specifically for the student of agriculture study program and the research finding will give the excellent effect in the education world. 
Desi Veranita, Syahrial, Irwan Koto, English for agriculture...

\section{REFERENCES}

Creswell, John W. (2014).Research design (qualitative, quantitative, mixed method approaches). University of nebrasca- Lincoln. America.

United State

Depdiknas. 2006. Kurikulum Tingkat Satuan Pendidikan SMK. Jakarta

Harding, K. (2007). English for specific purposes. Oxford. Oxford University Press.

Javid, Choudary Zahid. (2013). English for Specific Purposes: Its Definition Characteristics, Scope, and Purposes. European Journal of Scientific Research.Taif University.

Karimi, Lotfollah, Bahador Sadeghi, et al. (2013). Agricultural Extention and Rural Development ESP Textbook Evaluation in $\mathrm{Bu}$ Ali Sina University. Iran

Kemendikbud. (2012). Dokumen Kurikulum 2013. Jakarta

Margono, S. (2014). Metodologi Penelitian Pendidikan. Jakarta. Rineka Cipta

Mazdayasna G, Tahririan, MH. (2008). Developing a profile of the ESP needs of Iranian students: The case of students of nursing and midwifery Azad University Yazd, Iran. Sheikhbabaee University, Iran.

Permendiknas. No 22 tahun 2006. (2006). Standar Isi Untuk Satuan Pendidikan Dasar dan Menengah. Jakarta

Permendikbud no 70 tahun 2013. (2013). Kerangka Dasar Struktur Kurikulum Sekolah Menengah Kejuruan/ Madrasah Aliyah Kejuruan. Jakarta

Rata, georgeta. Florin sala. Et al. (2012). Agriculture English. Cambridge Scholars Publishing. Cambridge
Songhori, Mehdi Haseli. (2008). Introduction to Needs Analysis. Shahi Bahonar University. Kerman

Sugiyono. (2010). Metode Penelitian Pendidikan: Pendekatan Kuantitatif, Kualitatif, dan $R \& D$. Bandung. Alfabeta

Tomlinson, Brian. (2001). Materials Development in Language Teaching Cambridge. Cambridge University Press.

Zaremba, A.J. (2006). Speaking Professionaly. Thompson South-Western. Canada 